\title{
Molecule-Specific Imaging Analysis of Carcinogens in Breast Cancer Cells Using Time-of-Flight Secondary Ion Mass Spectrometry
}

J.N. Quong, M.G. Knize, K.S. Kulp, K.J. Wu

This article was submitted to

$14^{\text {th }}$ International Meeting on Secondary lon Mass Spectrometry San Diego, CA, September 14-19, 2003

August 19, 2003 


\section{DISCLAIMER}

This document was prepared as an account of work sponsored by an agency of the United States Government. Neither the United States Government nor the University of California nor any of their employees, makes any warranty, express or implied, or assumes any legal liability or responsibility for the accuracy, completeness, or usefulness of any information, apparatus, product, or process disclosed, or represents that its use would not infringe privately owned rights. Reference herein to any specific commercial product, process, or service by trade name, trademark, manufacturer, or otherwise, does not necessarily constitute or imply its endorsement, recommendation, or favoring by the United States Government or the University of California. The views and opinions of authors expressed herein do not necessarily state or reflect those of the United States Government or the University of California, and shall not be used for advertising or product endorsement purposes.

This is a preprint of a paper intended for publication in a journal or proceedings. Since changes may be made before publication, this preprint is made available with the understanding that it will not be cited or reproduced without the permission of the author.

This report has been reproduced directly from the best available copy.

Available electronically at http://www.doc.gov/bridge

Available for a processing fee to U.S. Department of Energy

And its contractors in paper from

U.S. Department of Energy

Office of Scientific and Technical Information

P.O. Box 62

Oak Ridge, TN 37831-0062

Telephone: (865) 576-8401

Facsimile: (865) 576-5728

E-mail: reports@adonis.osti.gov

Available for the sale to the public from

U.S. Department of Commerce

National Technical Information Service

5285 Port Royal Road

Springfield, VA 22161

Telephone: (800) 553-6847

Facsimile: (703) 605-6900

E-mail: orders@ntis.fedworld.gov

Online ordering: http://www.ntis.gov/ordering.htm

OR

Lawrence Livermore National Laboratory

Technical Information Department's Digital Library

http://www.llnl.gov/tid/Library.html 


\title{
Molecule-specific imaging analysis of carcinogens in breast cancer cells using time- of-flight secondary ion mass spectrometry
}

\author{
J. N. Quong ${ }^{*}$, M. G. Knize ${ }^{+} \&$ K. S. Kulp ${ }^{+}$, K. J. Wu ${ }^{*}$ \\ ${ }^{*}$ Chemistry and Materials Science Division \\ ${ }^{+}$Biology and Biotechnology Research Program \\ Lawrence Livermore National Laboratory \\ Livermore, CA 94550
}

\begin{abstract}
Imaging time-of-flight secondary ion mass spectrometry (TOF-SIMS) is used to study the localization of heterocyclic amines in MCF7 line of human breast cancer cells. The detection sensitivities of a model rodent mutagen, 2-amino-1-methyl-6-

phenylimidazo[4,5-b]pyridine (PhIP) were determined. Following an established criteria for the determination of status of freeze-fracture cells, the distribution of $\mathrm{PhIP}$ in the MCF7 cells are reported.
\end{abstract}

Keywords: TOF-SIMS, imaging, MCF7 cell 


\section{Introduction}

Heterocyclic amines are genotoxic carcinogens produced during cooking by the condensation of natural precursors. $[1,2]$ Of the several mutagens identified, 2-amino-1methyl-6-phenylimidazo[4,5-b]pyridine, $\mathrm{PhIP},\left(\mathrm{C}_{13} \mathrm{~N}_{4} \mathrm{H}_{12}, \mathrm{mw}=224.1\right)$ is found to be the most abundant produced at levels of 0.1-50 ng per gram of cooked meat.[3]. Animal experiments show PhIP to be carcinogenic in mice and rats. Published studies of rodent bioassays show that PhIP causes colon and prostate cancers in male rats and mammary cancer in female rats, interestingly hepatomas in the liver of either sex were not observed.[4]

Humans are exposed to PhIP through the consumption of cooked beef, pork and chicken. The levels found in these meats suggest that humans may be exposed to as much as micrograms per day in their diet.[5] The impact of PhIP exposure on human health is not clear and its contribution to human cancer is a current subject of debate. To cause a cellular effect, PhIP must be first metabolized and subsequently transported to the nucleus where it binds to DNA. Therefore, understanding the carcinogen's subcellular localization, movement through the various cellular compartments and the metabolic activation steps will help determine the role of a carcinogen, implicated in human cancer etiology.

We applied imaging time-of-flight secondary ion mass spectrometry (TOF-SIMS) to localize PhIP in the human breast cancer cell line MCF-7. The MCF-7 cell line is considered as a good model of hormone-dependent, relatively well differentiated, breast cancer.

\section{Experimental}

PhIP was purchased from Toronto Research chemicals, Toronto Canada. Dilutions of $\mathrm{PhIP}$ in water were pipetted using a robotic sample spotter in a volume of $0.5 \mu 1$. All tissue culture reagents and media were obtained from Gibco BRL Life Technologies (Grand Island NY). MCF-7 human breast adenocarcinoma cells were obtained from American Type Culture Collection (Manassas, VA). Latex beads (6 and $9 \mu \mathrm{m}$ diameter) were purchased from Duke Scientific Corp. (Palo Alto, CA).

For cryogenic sample preparation 40,000 cells $/ \mathrm{ml}$ were plated in $60 \mathrm{~mm}$ dishes that contained 1 to 3 silicon substrate $\left(1 \mathrm{~cm}^{2}\right)$. The Si chips were sterilized prior to seeding by UV irradiation. Cells were grown on the polished side of the silicon substrate for up to 3 days with no change in cellular growth or morphology, as compared to cells grown on the routine plastic substrate. Approximately 10,000 latex beads ( 6 or $9 \mu \mathrm{m}$ diameter) in $10 \mu \mathrm{l}$ phosphate-buffered saline (PBS) were added to the dish on the second day after seeding. The beads act as spacers during sample preparation. Forty-eight hours after plating the cells were treated with DiI $(6.7 \mu \mathrm{g} / \mathrm{ml})$ (Molecular Probes, Eugene OR), and/or PhIP (83 $\mu \mathrm{g} / \mathrm{ml}$ ) for 2 hours. 
To prepare cells for image analysis, the samples were prepared using a sandwich fracture method described by Chandra et al.[6] Briefly, cells were washed twice with $5 \mathrm{ml}$ ice cold PBS, followed by $5 \mathrm{ml}$ ice cold PBS contain latex beads $(10,000 / \mathrm{ml})$. The silicon chips with attached cells were sandwiched with a glass cover slip or a clean silicon piece and flash-frozen in liquid nitrogen-cooled isopentane for 1 minute. The frozen sandwich was transferred to a liquid nitrogen cooled metal block and snapped apart with a razor blade The substrate side of the sandwich was placed in a cold glass vial and then lyophilized overnight. The samples were stored at $0^{\circ} \mathrm{C}$ until analyzed by TOF/SIMS.

The TOF-SIMS measurements were conducted on a PHI TRIFT III instrument equipped with $\mathrm{Ga}, \mathrm{Cs}$ and $\mathrm{O}$ ion sources. The gallium $\left({ }^{69} \mathrm{Ga}^{+}\right)$liquid metal ion gun (LIMG) operated at $25 \mathrm{kV}$ was used as the primary ion source for experiments conducted in this report. The sample was held at room temperature during the course of the TOF-SIMS measurements.

\section{Results and discussion}

The objective of this study is to apply TOF-SIMS imaging for the localization of carcinogens in human breast cancer lines. A collection of relevant heterocyclic amines were analyzed by TOF-SIMS to determine their relative ionization yields. PhIP and others produce the desired minimum fragmentation and strong positive molecular ions, and PhIP was chosen for this work.

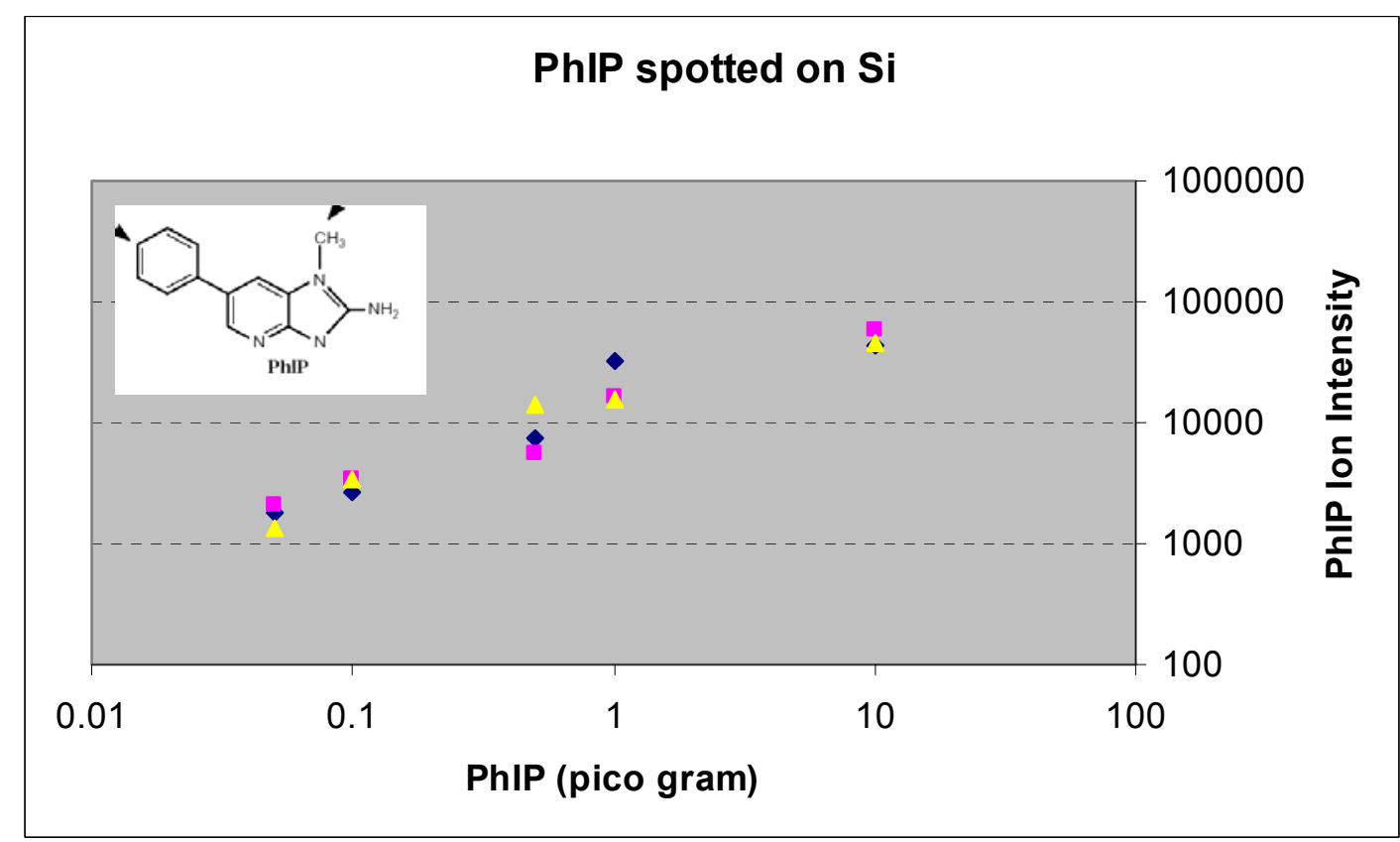

Figure 1 PhIP ion intensity as a function of concentration. Three measurements were conducted at each concentration level.

We examined the detection sensitivity of PhIP by TOF-SIMS by measuring the molecular ion signal intensity as a function of PhIP surface concentration as shown in Figure 1. 
Approximately 100 femtogram, or 4 atto mol deposited onto a ca. $2 \mathrm{~mm}$ diameter spot can be routinely detected. Assuming uniformly distributed over the sample surface, the practical detection sensitivity of PhIP would be in the order of 40 zepto mole over an average size cell surface. Such empirically determined detection limits for $\mathrm{PhIP}$ is essential for us to control and prepare the PhIP exposure needed for MCF-7 cell sample preparation.

Two criteria were applied to assess the status of cell freeze fracture sample preparation[7] First we compared $\mathrm{Na}$ and K. Cross-fractured cells expose the inner cytoplasm, which contains higher levels of potassium; hence relatively high $\mathrm{K} / \mathrm{Na}$ ion intensity ratio indicates fracture success. Secondly, we compared the natural cell component phosphocholine and the added dye molecule DiI. Assuming DiI inserts its tail groups into the lipophilic interior of membranes and is specific to the outer leaflet membrane; the absence of the DiI signal on the cell surface would indicate that inner cytoplasm is exposed. Ions related to phosphatidylcholine (PC) such as $\mathrm{m} / \mathrm{z}=184,224$ (phosphocholine head and tail group, respectively) are used to identify and confirm the image of MCF7 cells.

Positive ion images of a PhIP treated MCF-7 cell are shown in Figure 2. The coincidence of PhIP and the cell membrane marker phosphocholine suggests the cell is not fracture and $\mathrm{PhIP}$ is on the outer membrane.

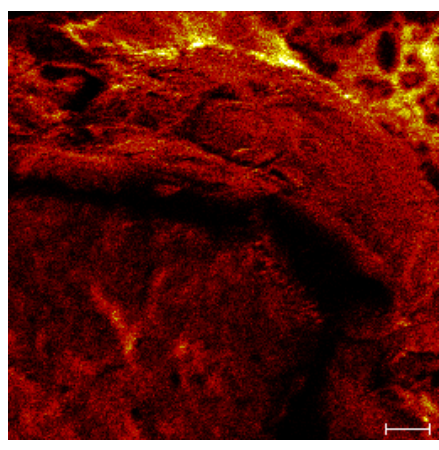

Total ion

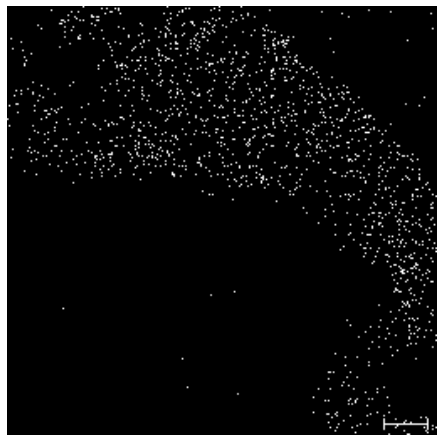

Phosphocholine, $m / z=184$

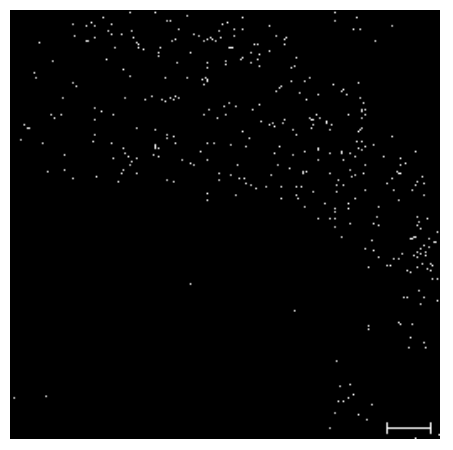

$\operatorname{PhIP}, \mathrm{m} / \mathrm{z}=225$

Figure 2 Positive ion images of MCF-7 cell treated with PhIP, image area is 50u x 50u, the scale bar corresponds to $10 \mathrm{u}$.

Figure 3 shows a collection of positive ion images of MCF-7 cells. The identification of cells in the image was determined by the images of $\mathrm{PC}$ related peaks at $\mathrm{m} / \mathrm{z}=184$. Several cells with different fractured states are presented in the $100 \mathrm{u} \times 100 \mathrm{u}$ imaging area. By applying the criteria above, MCF7 cell \#1 (indicated by arrow) exhibits high K/Na ratio while DiI and phosphocholine are both present at the surface. Therefore, we concluded that this cell was not fractured but its outer leaflet exposed. The imaging analysis was in fact conducted on the membrane surface of outer leaflet. The localization of PhIP was 
observed on the outer leaflet. It is most likely the residue from the PhIP treatment and maintained its chemical structure (non-metabolized).

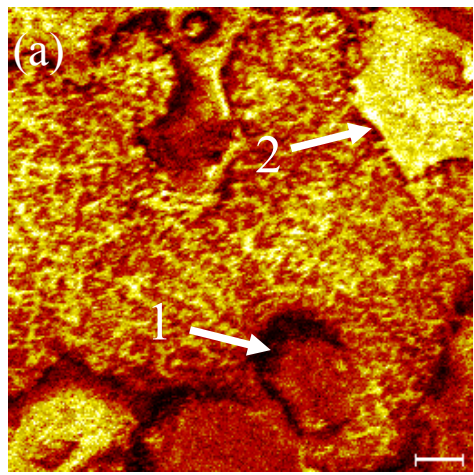

positive Ion

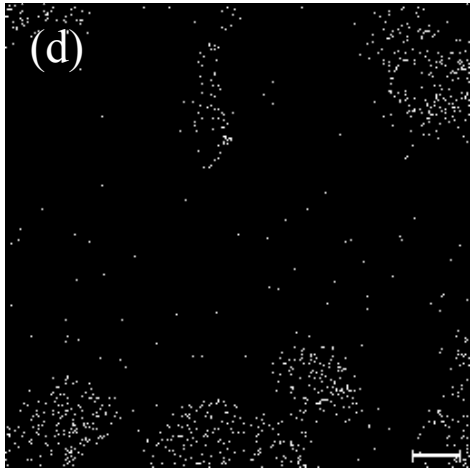

Phosphocholine

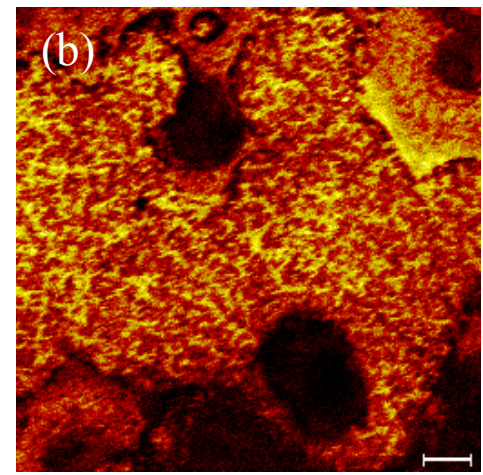

$\mathrm{Na}$

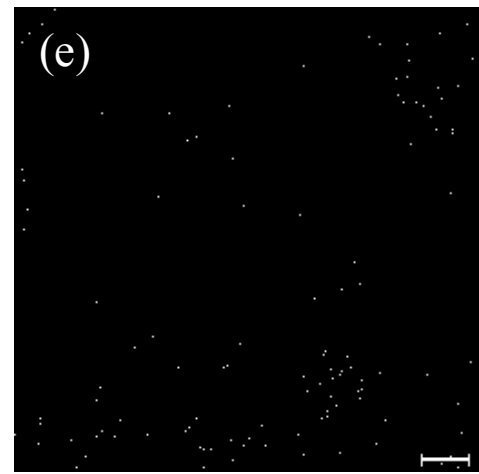

$\mathrm{PhIP}, \mathrm{m} / \mathrm{z}=225$

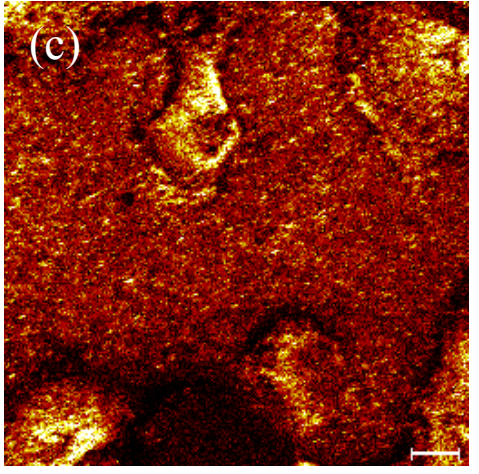

K

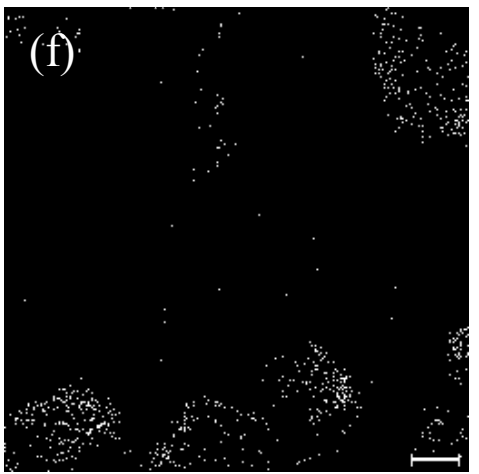

DiI, $m / z=834$

Figure 3 Positive ion images of MCF7 cells. The analysis area is $100 \mathrm{u} \times 100 \mathrm{u}$.

The cell \#2 exhibited different morphology with nucleus visible near the edge of the imaging area. The high $\mathrm{K} / \mathrm{Na}$ ratio in the nucleus demonstrates that the cell was persevered in its native state. Although the overall PhIP signal intensity was low within MCF cell \#2, PhIP appears to be localized in the cytoplasm region and is absent inside the nucleus. Such observation is attributed to the short treatment time and such relatively short time is insufficient for a complete PhIP transport to nucleus. Time resolved study of PhIP uptake will be conducted in the near future.

\section{Summary}

Imaging time-of-flight secondary ion mass spectrometry is used to acquire chemical specific images for the studies of heterocyclic amine in human breast cancer cells. The detection sensitivity of PhIP was determined to be at zepto mol range on the cellular level. By correlating the ion images of $\mathrm{Na}, \mathrm{K}$, phosphocholine and DiI on the cell surface, we have established a set of basic working criteria for determining the status of 
cell fracture. Localization of PhIP was successfully observed primarily on the surface of outer leaflet membrane. The future studies will focus on the improvement of ionization yields such as different primary ion source and surface enhancement approach. We will continue to progress our sample preparation technique, which will no doubt to play a pivotal role in the overall success of this project.

\section{Acknowledgment}

This work was performed under the auspices of the U.S. Department of Energy by the University of California, Lawrence Livermore National Laboratory under contract No. W-7405-Eng-48. Additional support from National Cancer Institute grant CA55861 is gratefully acknowledged.

\section{References}

1. Nagao, M., Sugimura, T., Eds, 2000, Food Borne Carcinogens Heterocyclic Amines, John Wiley \& Sons, West Sussex, England.

2. Felton, J. S., Knize, M. G., Shen, N. H., Lewis, P. R., Anderson, B. D., Happe, J. and Hatch, F. T., Carcinogenesis 7, 1081-1086, 1986.

3. Pais, P., Tanga, M. J., Salmon, C. P. and Knize, M. G., Formation of the Mutagen IFP in Model Systems and Detection, 2000

4. Shirai, T. Sano, M., Tamano, S., Takahashi, S., Hirose, T., Futakuchi, M., Hasegawa, R., Imaida, K., Matsumoto, K-I., Wakabayashi, K., Sugimura, T. Ito, N. Cancer Research, 57, 195-198, 1997.

5. Knize, M. G., Sinha, R., Rothman, N., Brown, E. D., Salmon, C. P., Levander, O. A., Cunningham, P. L. and Felton, J. S., Food Chem. Toxic. 33, 545-51, 1995.

6. Chandra, S., Morrison, G. H. and Wolcott, C. C., J. Microsc. 144, 15-37, 1986.

7. Roddy, T. P., Cannon, D. M., Ostrowski, S. G., Winograd, N., and Ewing, A. G., Anal. Chem., 74, 4020-4026, 2002. 